\title{
PENGARUH INTERKALASI MIKRO MONTMORILLONIT DENGAN MIKRO KITOSAN SEBAGAI ADSORBEN UNTUK MENINGKATKAN MUTU MINYAK NILAM
}

\author{
Febri Susanti ${ }^{1}$, Tisna Harmawan ${ }^{* 1}$, Puji Wahyuningsih ${ }^{1}$ \\ 1)Departemen Kimia, Fakultas Teknik - Universitas Samudra, Langsa, Aceh \\ Jl. Meurdaneh, Langsa, Aceh, Indonesia \\ E-mail: tisna_harmawan@unsam.ac.id
}

Received : 27 Agustus 2021 ; revised : 29 Agustus 2021 ; accepted : 28 Sepember 2021

\begin{abstract}
ABSTRAK
PENGARUH INTERKALASI MIKRO MONTMORILLONIT DENGAN MIKRO KITOSAN SEBAGAI ADSORBEN UNTUK MENINGKATKAN MUTU MINYAK NILAM. Telah dilakukan interkalasi Mikro MMT dengan Mikro kitosan sebagai adsorben untuk meningkatkan mutu minyak nilam. Tujuan dari penelitian ini adalah mengisolasi Mikro MMT dari bentoit dan menginterkalasinya pada mikro kitosan untuk membuat suatu adsorben serta melihat peningkatan mutu minyak nilam dengan penambahan adsorben Mikro MMT dengan Mikro kitosan. Hasil karakterisasi XRD menunjukkan adanya peningkatan basal spacing dari 7,9497 ̊̊menjadi 8,3537 ̊ setelah diinterkalasi dengan Nanokitosan ke dalam interlayer Mikro MMT, hal ini mendanakan bahwa Mikro kitosan telah berhasil terinterkalasi ke dalam interlayer Mikro MMT. Pengujian minyak nilam menggunakan GC-MS menunjukkan adsorben Mikro MMT terinterkalasi dengan Mikro kitosan mengalami penurunan persen area PA sebesar $6,98 \%$ dari $39,33 \%$ menjadi $32,35 \%$. Perbdaningan pada minyak nilam murni dengan adsorben Mikro MMT dan Mikro kitosan mengalami peningkatan sebesar 2,05\%, dimana persen area PA pada minyak nilam murni adalah 30,30\% sedangkan persen area PA pada interkalasi Mikro MMT dan Mikro kitosan yaitu sebesar $32,35 \%$. Berdasarkan analisis tersebut dapat disimpulkan bahwa adsorben Mikro MMT dan Mikro kitosan dapat meningkatkan mutu minyak nilam.
\end{abstract}

Kata kunci : Minyak Nilam, Interkalasi, Mikro MMT, Mikro kitosan, Adsorben

\begin{abstract}
THE EFFECT INTERCALATION OF MIRO MONTMORILLONITE WITH MIRO CHITOSAN AS ADSORBENT FOR PATCHOULI OIL QUALITY IMPROVEMENT. Micro MMT intercalation with Micro chitosan as adsorbent has been carried out to improve the quality of patchouli oil. The purpose of this study was to isolate Micro MMT from bentonite dan intercalate it on Micro chitosan to make adsorbent dan to observe the improvement in the quality of patchouli oil by adding Micro MMT adsorbent with Micro chitosan. XRD characterization results showed an increase in basal spacing from $7.9497 \AA$ to $8.3537 \AA$ after intercalating with Micro chitosan into the Micro MMT interlayer, wich mean that the Micro chitosan has been successfully intercalated into the Micro MMT interlayer. Patchouli oil testing using GC-MS showed that the Intercalated Micro MMT adsorbent with Micro citosan decreased the percentage of $P A$ area by $6.98 \%$ from $39.33 \%$ to $32.35 \%$. The comparison of pure intercalation with Micro MMT dan Micro chitosan adsorbents has increased by $2.05 \%$, where the percentage area in pure patchouli oil PA is $30.30 \%$ while the percentage area in the Intercalation of Micro MMT dan Micro chitosan is $32.35 \%$. Based on this analysis, it can be concluded that the Micro MMT dan Micro chitosan adsorbent can improve the quality of patchouli oil.
\end{abstract}

Key words : Patchouli Oil, Intercalation, Micro MMT, Micro chitosan, Adsorbent

\section{PENDAHULUAN}

Minyak nilam merupakan minyak atsiri yang dapat diperoleh dari tanaman nilam (Pogostemon patchouli) dengan cara penyulingan. Bagian daun memiliki kdanungan minyak nilam tertinggi yaitu sekitar $4-5 \%$. Komponen utama yang menentukan mutu minyak nilam adalah patchouli alcohol yang merupakan senyawa kelompok seskuiterpen alkohol tersier trisiklik yang mempunyai gugus hidroksil dan 4 buah gugus metil. Semakin tinggi kadar Patchouli alcohol (PA) dalam minyak nilam maka semakin baik kualitas minyak tersebut (Zaimah 2014). PA termasuk salah satu komponen penentu harga jual minyak nilam di pasar dunia. Semakin besar kadar PA dalam minyak nilam, maka semakin mahal harga jualnya. Berdasarkan Standar Nasional Indonesia 2006 tentang minyak nilam yang 
menyatakan bahwa syarat kadar baku PA dalam minyak nilam minimal $30 \%$ dengan indeks bias berkisar 1,507 - 1,515 (Ismuyanto et al. 2015).

Indonesia merupakan produsen minyak nilam terbesar di dunia dengan kisaran kontribusi sebesar $90 \%$ sebagai penyumbang devisa negara (Kurniasari et al., 2010). Hal ini dikarenakan minyak tersebut memiliki volume yang cukup besar dan mempunyai nilai jual yang tinggi dalam ekspor minyak atsiri Indonesia (Septiana et al., 2012). Pengumpulan dan karakterisasi plasma nutfah nilam telah dilakukan Balai Penelitian Tanaman Obat dan Aromatik (Balittro) dan didapatkan 3 varietas unggul nilam yaitu Sidikalang, Tapak Tuan dan Lhokseumawe (Haryudin dan Maslahah, 2011). Sentra produksi minyak nilam Indonesia adalah di daerah Aceh seperti Gayo Lues, Aceh Tamiang dan Aceh Timur, namun masih ditemui kendala terkait mutu hasil ekstraksi yang rendah.

Salah satu penyebab penurunan mutu minyak nilam adalah proses pengolahannya. Minyak dengan kualitas buruk akan terlihat pada tingkat kejernihan minyak dikarenakan adanya kontaminan. Salah satu penyebabnya adalah alat suling tradisional dengan tangki bekas drum minyak yakni di dalam minyak ion logam seperti magnesium, besi, mangan, tembaga, plumbum, dan seng dapat terlarut. Kontaminasi dari logam besi dan tembaga pada drum biasanya menyebabkan warna minyak yang dihasilkan akan terlihat lebih gelap dan berwarna kehitaman atau sedikit kehijauan (Harti et al., 2014), maka dari itu dilakukan pemurnian untuk meningkatkan mutu minyak nilam dengan penambahan material maju Mikro montmorillonit (Mikro-MMT) yang banyak ditemukan di Kabupaten Aceh Tamiang, Provinsi Nanggroe Aceh Darussalam.

Montmorillonit (MMT) merupakan kelompok mineral filosilikat yang memiliki kemampuan untuk mengembang serta kemampuan untuk berinterkalasi dengan senyawa organik membentuk material komposit. Selain itu mineral ini juga mempunyai kapasitas penukar kation yang tinggi sehingga ruang antar lapis MMT mampu mengakomodasi kation dalam jumlah yang besar serta menjadikan MMT sebagai material yang unik (Harmawan et al., 2021; Wahyuningsih et al., 2020; Zaimahwati et al., 2018). MMT digunakan sebagai adsorben karena bersifat hidrofilik sehingga memiliki kapasitas adsorpsi yang rendah terhadap senyawa organik (Machiril et al., 2017). MMT harus dimodifikasi dengan menyisipkan senyawa lain untuk meningkatkan daya adsorpsinya (Sari et al.,2013). Penggunaan MMT sebagai adsorben pada minyak nilam bertujuan untuk menyerap pengotor-pengotor yang ada di dalam minyak nilam sehingga pemurnian minyak nilam menggunakan MMT dapat meningkatkan kualitas minyak nilam. Salah satu cara meningkatkan kinerja MMT yaitu dengan menginterkalasi menggunakan kitosan.

Tujuan interkalasi kitosan pada interlayer MMT yaitu meningkatkan daya adsorpsi MMT terhadap senyawa organik. Selain itu interkalasi kitosan pada interlayer MMT dapat meningkatkan luas permukaan MMT, keberadaan pasangan elektron bebas pada gugus hidroksil dan amina pada kitosan dapat bertindak sebagai ligan dan dapat berinteraksi dengan zat warna kationik atau kation logam melalui mekanisme pembentukan ikatan kovalen koordinasi (Machiril et al., 2017). Interkalasi didasari atas pertukaran kation yang terdapat pada antarlapis lempung, seperti ion $\mathrm{Na}^{+}, \mathrm{K}^{+}$, dan $\mathrm{Ca}^{2+}$. Interkalasi ke dalam struktur lempung mengakibatkan peningkatan luas permukaan, basal spacing dan keasaman permukaan yang berpengaruh terhadap daya adsorpsinya (Suarya, P. dan Simpen 2009).

Penelitian yang telah dilakukan oleh Sari et al (2013) menggunakan MMT-kitosan untuk adsorpsi zat warna congo red didapatkan hasil bahwa adanya peningkatan basal spacing dan luas permukaan setelah interkalasi menggunakan kitosan. Hal yang sama dilakukan oleh Machiril et al (2017) yang telah melakukan penelitian tentang interkalasi MMT dengan kitosan serta aplikasinya sebagai adsorben methylene blue. Interkalasi tersebut mampu meningkatkan basal spacing, luas permukaan dan volume total pori. Berdasarkan penelitian yang telah dilakukan sebelumnya, dilakukan modifikasi terhadap MMT melalui rekayasa ukuran material menjadi nano partikel dan interkalasi menggunakan nanokitosan untuk meningkatkan daya adsorpsi terhadap minyak nilam sehingga meningkatkan mutu minyak nilam.

Berdasarkan latar belakang, dilakukan penelitian interkalasi Mikro MMT dengan kitosan (Mikro MMT - Mikro kitosan) serta aplikasinya sebagai adsorben untuk meningkatkan mutu minyak nilam.

\section{BAHAN DAN METODE}

\section{Bahan dan Alat}

Sampel yang digunakan dalam penelitian ini adalah minyak nilam (Pogostemon patchouli) dari Gayo Lues. Bahan-bahan yang digunakan dalam penelitian ini adalah Bentonit yang mengdanung MMT yang diperoleh dari Kabupaten Aceh Tamiang, Provinsi Nanggroe Aceh Darussalam, kitosan (Derajat Deasetilasi = 83,5\%) yang diperoleh dari CV. Ocean Fresh Bdanung, Akuades, Natrium Tripoliphospat, Tween 80, Asam Asetat, Asam Klorida, dan Natrium Hidroksida. Sedangkan alat yang digunakan dalam penelitian ini adalah neraca analitik, kertas saring whatman 42, kaca arloji, pipet ukur, gelas kimia, erlenmeyer, ayakan 250 
mesh, hot plate dan magnetic stirrer, pH meter HI 98107 (Hanna, USA) serta seperangkat alat High Energy Milling (HEM) SPEX CertiPep 8000 M (USA), Particle Size Analyzer (PSA) SZ-100 (Horiba Scientific, Japan), X-Ray Diffraction (XRD) 6000 (Shimadzu, Japan) dan Gas Cromatography Mass Spectrometry (GC-MS) YL 6900 (Shimadzu, Japan).

\section{Metode}

Metode yang digunakan pada penelitian ini meliputi isolasi mikro montorillonit dari Bentonit asal Aceh Tamiang, pembuatan mikro kitosan, interkalasi mikro montmorillonit dengan mikro kitosan dan adsorbsi minyak nilam.

\section{a. Isolasi Mikro Montmorillonit (Mikro MMT) dari Bentonit}

Bentonit ditumbuk hingga halus menggunakan alu dan mortar kemudian disaring dengan ayakan 250 mesh. Sebanyak $50 \mathrm{~g}$ bentonit ditimbang dan dimasukkan ke dalam ultrasonicc batch yang telah diisi dengan $2 \mathrm{~L}$ akuades. Selama 15 menit diberikan gelombang ultrasonic dengan daya 750 Watt pada suhu ruang. Serbuk bentonit hasil ultrasonic disaring menggunakan kertas saring whatman 42. Endapan yang diperoleh diambil sebagai fraksi 1. Selanjutnya filtrat ditampung dan diaduk sebanyak 3 kali menggunakan batang pengaduk, didiamkan selama 10 hari. Setelah 10 hari disaring kembali menggunakan kertas saring whatman 42. Kemudian diambil endapannya (fraksi 2). Filtrat diaduk kembali sebanyak 10 kali menggunakan batang pengaduk, selama 6 hari didiamkan. Setelah 6 hari disaring kembali menggunakan kertas saring whatman 42 . Endapan diambil sebagai fraksi 3. Filtratnya ditampung dan dikeringkan menggunakan oven sampai seluruh akuades menguap. Filtrat yang sudah kering sebagai fraksi 4 (Harmawan et al., 2019; Wahyudi, 2010). Fraksi 4 ditumbuk menggunakan alat High Energy Milling (HEM) kemudian dianalisis dengan alat Particle Size Analyzer (PSA) untuk menentukan ukuran Montmorillonit yang terbentuk. Serta menganalisis kristanilitas menggunakan X-Ray Diffraction (XRD) untuk membuktikan bahwa hasil yang diperoleh berupa Montmorillonit.

\section{b. Pembuatan Mikro Kitosan}

Kitosan dengan Derajat Deasetilasi 83,5\% sebanyak $3 \mathrm{~g}$ dilarutkan dalam asam asetat $2 \%(\mathrm{v} / \mathrm{v})$ sebanyak $1 \mathrm{~L}$ menggunakan magnetic stirer. Setelah 1 jam ditambahkan $25 \mathrm{~mL}$ tween 80 konsentrasi $0,2 \%(\mathrm{v} / \mathrm{v})$ dengan cara tetes demi tetes ke dalam kitosan yang telah mengalami pengecilan ukuran, dan diaduk selama 30 menit menggunakan magnetic stirer. Kemudian ditambahkan tripolifosfat $0,1 \%(\mathrm{~b} / \mathrm{v})$ sebanyak $200 \mathrm{~mL}$ secara perlahan yang bertujuan agar ukuran partikel yang dihasilkan tetap stabil. Kemudian larutan dipisahkan menggunakan sentrifugal dengan kecepatan 900 rpm pada suhu ruang selama 30 menit. Selanjutnya kitosan yang terbentuk ditentukan ukurannya dengan PSA, kemudian dikering anginkan (Yudhasasmita dan Nugroho, 2017).

\section{c. Interkalasi Mikro Montmorillonit dengan Mikro Kitosan \\ Serbuk mikro kitosan sebanyak $4 \mathrm{~g}$} dilarutkan dalam $196 \mathrm{~mL}$ asam asetat $2 \%(\mathrm{v} / \mathrm{v})$. Larutan mikro kitosan dalam asam asetat kemudian diaduk menggunakan magnetic stirrer selama 30 menit. Mikro MMT sebanyak 2,5 g didispersikan ke dalam $100 \mathrm{~mL}$ akuades kemudian diaduk menggunakan magnetic stirer selama 1 jam. Larutan mikro kitosan dalam asam asetat yang telah disiapkan ditambahkan secara perlahan, kemudian diaduk selama 24 jam menggunakan magnetic stirer. Larutan Mikro MMT dan Mikro kitosan disaring menggunakan kertas saring whatman 42 untuk memisahkan dari suspensi, kemudian dicuci dengan akuades hingga $\mathrm{pH}$ filtrat yang dihasilkan netral dan dikering anginkankan. Selanjutnya hasil interkalasi dikarakterisasi menggunakan $X$-Ray Diffraction (XRD) dengan kondisi alat menggunakan $\mathrm{Cu}-\mathrm{Ka}$ radiation, pada $40 \mathrm{kV}$ dan $30 \mathrm{~mA}$ (Machiril et al., 2017).

\section{d. Adsorbsi Minyak Nilam}

Adsorpsi dilakukan dengan membdaningkan penambahan $0,1 \mathrm{~g}$ adsorben Mikro MMT dan 0,1 g adsorben Mikro MMT Mikro kitosan ke dalam $25 \mathrm{~mL}$ minyak nilam dan campuran diaduk menggunakan magnetic stirer selama 24 jam. Setelah pengadukan selesai, larutan disaring menggunakan kertas saring whatman 42 dan diperoleh filtrat untuk dikarakterisasi menggunakan Gas Chromatography-Mass Spectrometry (GC-MS) (Machiril et al., 2017).

\section{HASIL DAN PEMBAHASAN}

\section{a. Isolasi Mikro Montmorillonit (Mikro MMT) dari Bentonit}

MMT yang digunakan sebagai adsorben untuk meningkatkan mutu minyak nilam diperoleh dari bentonit asal Kabupaten Aceh Tamiang. Ukuran partikel MMT diamati menggunakan PSA dengan air sebagai media pendispersinya. Pada Gambar 1 dan Tabel 1 menunjukkan grafik distribusi ukuran partikel MMT menggunakan PSA. Prinsip pengukuran PSA pada pengujian MMT ini menggunakan metoda Scattering Light Intensity. 


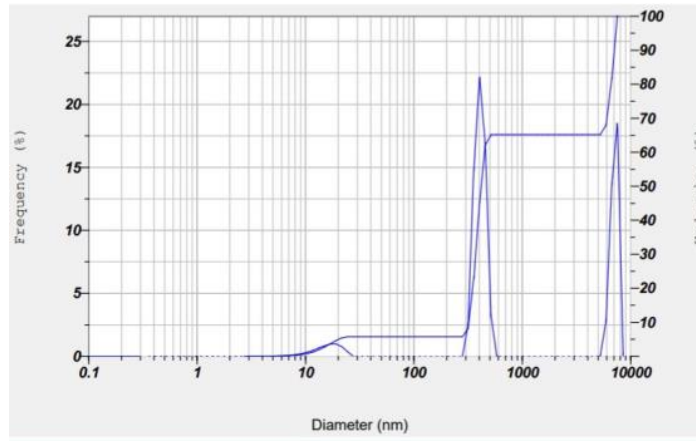

Gambar 1. Grafik Distribusi Ukuran Partikel MMT menggunakan PSA

Seperti yang telah dideskripsikan oleh Saputra et al (2011) bahwa nano partikel merupakan suatu material yang berskala nano meter dengan ukuran dari $1-100 \mathrm{~nm}$. Hasil pengukuran PSA menunjukkan bahwa MMT memiliki ukuran partikel nano sebanyak $6 \%$ dan selebihnya merupakan partikel mikropori. Semakin halus suatu partikel semakin besar pula luas permukaan yang dapat meningkatkan reaktifitas material. Material dalam skala mikrometer umumnya menunjukkan sifat-sifat yang hampir sama dengan bulk-nya (Muchtar et al ., 2015).

Informasi lainnya yang bisa diperoleh dari karakterisasi PSA ialah mengenai Polydispersity Index (PI) yang menyatakan tingkat kehomogenan partikel dimana bila nilai $\mathrm{PI}$ berkisar antara 0,10 - 0,70 menunjukkan bahwa nano partikel mempunyai tingkat homogenitas yang baik (monodispers), sedangkan mikro partikel yang memiliki nilai PI lebih dari 0,70 maka mikro partikel akan bersifat kurang stabil dan kurang homogen akibat distribusi ukuran partikel yang luas (Putri et al., 2018). Dari hasil pengukuran PI pada sampel MMT yaitu sebesar 0,75 maka dapat disimpulkan bahwa MMT yang dihasilkan pada penelitian ini mempunyai sifat kurang stabil dan kurang homogen distribusi ukuran partikel dikarenakan proses penghancuran pada alat HEM yang kurang merata. Hal ini didukung dengan distribusi ukuran partikel yang terlihat pada Tabel 1 dimana MMT memiliki ukuran partikel $15,3 \mathrm{~nm}$ (6\%), 383,9 nm (59\%) dan 6647,1 nm (35\%).

\begin{tabular}{lcl} 
Tabel & $\begin{array}{c}\text { 1. Hasil Pengukuran Ukuran Partikel } \\
\text { MMTmenggunakan PSA }\end{array}$ \\
\hline Peak No & $\begin{array}{c}\text { Summating } \\
\text { Potential } \\
\text { Area Ratio }\end{array}$ & Mean $(\mathrm{nm})$ \\
& 0,06 & 15,3 \\
\hline 1. & 0,59 & 383,9 \\
2. & 0,35 & 6647,1 \\
3. &
\end{tabular}

\begin{tabular}{lll} 
Total & 1,00 & 2546,8 \\
\hline Z-Average & 2122,5 \\
\hline PI & 0,75 \\
\hline
\end{tabular}

\section{b. Pembuatan Mikro Kitosan}

Prinsip pengukuran PSA pada pengujian kitosan ini menggunakan metoda Scattering Light Intensity. Pengujian ini didasarkan oleh difraksi laser, sehingga diperoleh distribusi ukuran partikel melalui penghamburan cahaya pada sudut yang berbeda sesuai dengan ukuran partikel. Partikel besar akan menghambur pada sudut kecil sementara partikel kecil akan menghambur pada sudut besar (Muchtar et al., 2015). Gambar 2 dan Tabel 2 menunjukkan grafik distribusi ukuran partikel kitosan yang dikarakterisasi menggunakan PSA. Berdasarkan Gambar 2 dapat diklasifikasikan kitosan sebagai partikel berukuran mikro karena memiliki rentang ukuran pada range $120,9 \mathrm{~nm}$ dengan presentasi sebesar $18 \%$ dan $477,7 \mathrm{~nm}$ dengan presentasi sebesar $82 \%$.

Hasil pengukuran partikel kitosan memiliki nilai ukuran rata-rata sebesar $341,3 \mathrm{~nm}$ dan nilai

PI sebesar 0,33 sehingga dapat dikatakan bahwa kitosan yang dihasilkan pada penelitian ini mempunyai tingkat homogenitas yang baik karena memiliki nilai PI yang kecil dibawah 0,70.

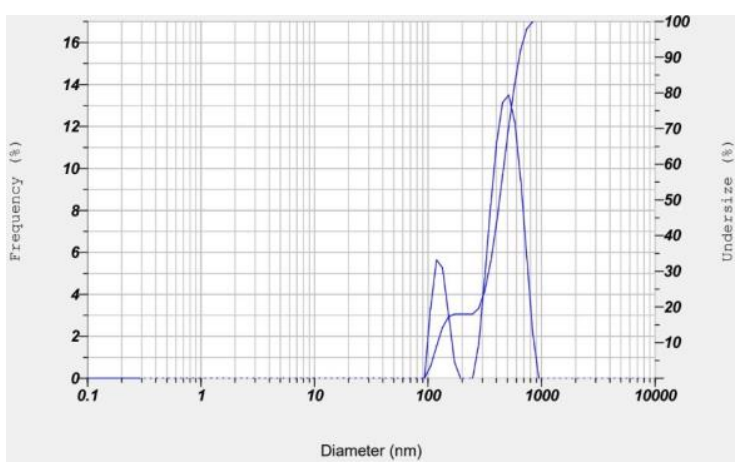

Gambar 2. Grafik Distribusi Ukuran Partikel Kitosan menggunakan PSA

Tabel 2. Hasil Pengukuran Ukuran Partikel Kitosan menggunakan PSA

\begin{tabular}{lcc}
$\begin{array}{c}\text { Peak } \\
\text { No }\end{array}$ & $\begin{array}{c}\text { Summating } \\
\text { Potential Area } \\
\text { Ratio }\end{array}$ & Mean (nm) \\
\hline 1. & 0,18 & 120,9 \\
2. & 0,82 & 477,7 \\
Total & 1,00 & 413,6 \\
\hline & Z-Average & 341,3 \\
\hline & PI & 0,330
\end{tabular}




\section{c. Interkalasi Mikro Montmorillonit dengan Mikro Kitosan}

Karakteristik MMT yaitu memiliki lapisan silikat yang berlapis biasanya bermuatan negatif sehingga memungkinkan terjadinya reaksi dengan pertukaran kation (Riskina et al., 2018). Ruang antar lapisan ditempati oleh kation. Reaksi pertukaran kation antar lempung dan kation organik pada lapisan silikat dapat ditransformasikan ke dalam struktur lempung. MMT dapat digunakan sebagai adsorben yang baik karena bersifat hidrofilik, maka dari itu untuk meningkatkan kualitas daya serapnya dilakukanlah interkalasi MMT dengan kitosan. Interkalasi MMT dilakukan dengan menukarkan kation-kation yang berada antar lapis dengan polikation anorganik yang berukuran lebih besar. Kitosan merupakan polimer kationik yang memiliki monomer sebanyak 2000-3000 (Sumarlan et al., 2013). Interkalasi kitosan ke dalam struktur MMT mengakibatkan basal spacing dan luas permukaan MMT meningkat, pori-pori lempung semakin besar dan homogen serta antar lapisnya pun menjadi lebih stabil dibdaningkan sebelum interkalasi.

Untuk menganalisis kdanungan mineral, menentukan fasa dan struktur kristal suatu material dapat diuji menggunakan XRD. Karakterisasi menggunakan XRD dilakukan untuk membdaningkan nilai $2 \theta$ Mikro MMT sebelum diinterkalasi dan setelah diinterkalasi menggunakan Mikro kitosan. Pola difraksi sinar $X$ MMT sebelum diinterkalasi dan setelah diinterkalasi dengan mikro kitosan ditunjukkan pada Gambar 3. Berdasarkan Gambar 3, terjadi perubahan komposisi secara signifikan yang ditdanai dengan menurunnya puncak $2 \theta$ yang dihasilkan dari proses interkalasi kitosan pada ruang antar lapis MMT. Beberapa puncak yang menunjukkan puncak-puncak khas mineral MMT pada $2 \theta=11,1210 ; 12,0411$ dan $12,9585^{\circ}$ dengan nilai basal spacing 7,$9497 ; 7,3442$ dan $6,8263 \AA$ A. Setelah diinterkalasi dengan kitosan, puncak $2 \theta$ tersebut mengalami pergeseran ke kiri menjadi 10,$5815 ; 11,3970$ dan $12,8707^{\circ}$ dengan nilai basal spacing 8,$3537 ; 7,7578$ dan $6,8726 \AA$ Å seperti yang ditunjukkan pada Tabel 3 .

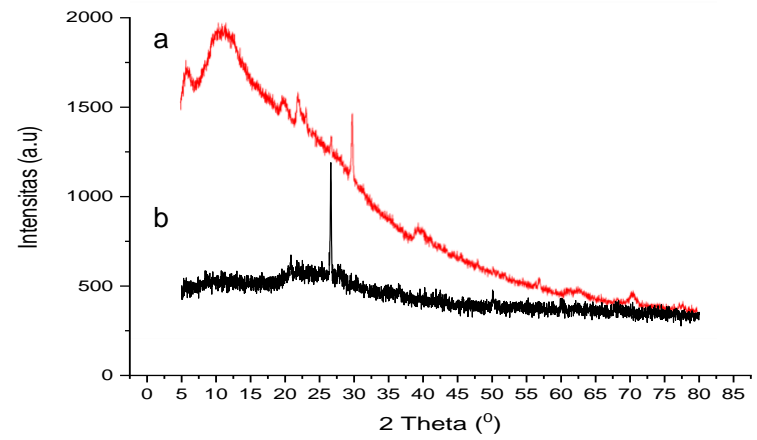

Gambar 3. Difraktogram Sinar-X (a) Mikro MMT (b)

Hasil Interkalasi Mikro MMT dengan Mikro Kitosan

Hasil penelitian menunjukkan bahwa nilai jarak antarlapis (basal spacing) relatif tidak mengalami perubahan, interkalasi Mikro MMT dengan Mikro kitosan memiliki basal spacing yang sedikit lebih besar dari Mikro MMT yang belum diinterkalasi. Hal ini ditdanai dengan adanya pergesaran sudut $2 \theta$ ke arah yang lebih kecil dan adanya peningkatan basal spacing yang menyatakan bahwa kitosan telah berhasil diinterinterkalasikan ke dalam interlayer Mikro MMT (Machiril et al., 2017).

Tabel 3. Data Puncak Difraktogram Sinar X

Peak No $2 \theta\left({ }^{\circ}\right)$

Basal spacing $(\AA)$

\begin{tabular}{ccccc} 
& Sebelum Interkalasi & Setelah Interkalasi & Sebelum Interkalasi & Setelah Interkalasi \\
\hline 4 & 11,1210 & 10,5815 & 7,9497 & 8,3537 \\
5 & 12,0411 & 11,3970 & 7,3442 & 7,7578 \\
6 & 12,9585 & 12,8707 & 6,8263 & 6,8726
\end{tabular}

\section{d. Adsorbsi Minyak Nilam}

Aktivitas adsorbsi minyak nilam dilakukan dengan membdaningkan hasil pengamatan pada penambahan Mikro MMT dengan hasil interkalasi Mikro MMT dan Mikro kitosan. Pengamatan perubahan warna pada minyak nilam dilakukan secara visual pada jarak $20 \mathrm{~cm}$ dari pengamat. Hal yang menyebabkan perubahan warna minyak nilam menjadi semakin jernih karena adsorben hasil interkalasi mikro MMT dengan mikro kitosan akan mengadsorpsi komponen-komponen pengotor yang terdapat dalam minyak nilam (Hardyanti et al., 2016).

Warna yang dihasilkan pada minyak nilam dapat dipengaruhi oleh komponen penyusun yang terdapat di dalamnya serta teknik pengolahan yang masih bersifat tradisional menggunakan drum bekas menyebabkan minyak nilam terkontaminasi. Minyak yang berwarna gelap dan kehitaman mendanakan bahwa minyak tersebut telah terkontaminasi ion logam berat seperti $\mathrm{Pb}^{+}, \mathrm{Fe}^{2+}$ dan $\mathrm{Cu}^{2+}$ Berdasarkan hasil proses adsorpsi menggunakan adsorben hasil interkalasi mikro 
MMT dengan Mikro kitosan menunjukkan bahwa warna minyak nilam berubah menjadi kuning muda seperti yang ditunjukkan pada Tabel 4 . Hal ini dikarenakan nano-MMT dan kitosan memiliki gugus-gugus bermuatan negatif yang mampu mengadsorpsi komponen-komponen pengotor, khususnya logam-logam berat yang bermuatan positif dalam minyak nilam (Hardyanti et al., 2016). Tingkat kejernihan minyak nilam menentukan kualitas minyak nilam. Semakin jernih maka semakin baik mutu minyak nilam yang dihasilkan.

Kitosan mampu menyerap logam dikarenakan adanya gugus amina dan hidroksil, sehingga kitosan memiliki reaktivitas yang tinggi dan mempunyai sifat polielektrolit kation. Akibatnya kitosan dapat berperan sebagai penukar ion dan dapat berperan sebagai adsorben. Gugus amina berperan sebagai kation yang mampu berikatan dengan logam berat. Gugus amina sebagai pengkelat yang akan mengikat logam tersebut. Berdasarkan SNI 062385-2006 tentang minyak nilam, syarat mutu minyak nilam rentang warna minyak nilam yaitu dari coklat kemerahan hingga kuning muda. Berdasarkan Gambar 5 dan Tabel 4 dapat disimpulkan bahwa minyak nilam yang dihasilkan setelah adsorpsi telah memenuhi syarat mutu minyak nilam. Kontaminan yang menyebabkan warna minyak nilam yang dihasilkan berwarna gelap akan teradsorpsi dengan baik dengan adanya penambahan adsorben hasil interkalasi mikro MMT dan mikro kitosan (Harti et al., 2014).

Minyak nilam merupakan minyak atsiri yang bersifat volatil, maka dari itu untuk mendeteksi senyawa yang terdapat dalam minyak tersebut dilakukan karakterisasi menggunakan alat GC-MS. Sesuai dengan SNI 06-2385-2006 yang membahas tentang syarat mutu minyak nilam diketahui bahwa kadar minimum Patchouli alcohol (PA) adalah sebesar $30 \%$.

Tabel 4. Perubahan Warna Minyak Nilam

\begin{tabular}{llc}
\hline No & Sampel & Warna \\
\hline (a) & Minyak Nilam Murni & 2 \\
(b) & Minyak Nilam+ Mikro MMT & 3 \\
(c) & Minyak Nilam+ Mikro MMT+ & 4 \\
& Mikro Kitosan & \\
\hline
\end{tabular}
Keterangan warna:
$0=$ Hitam
$1=$ Coklat kehitaman
2 = Coklat kemerahan
$3=$ Coklat kekuningan
$4=$ Kuning muda
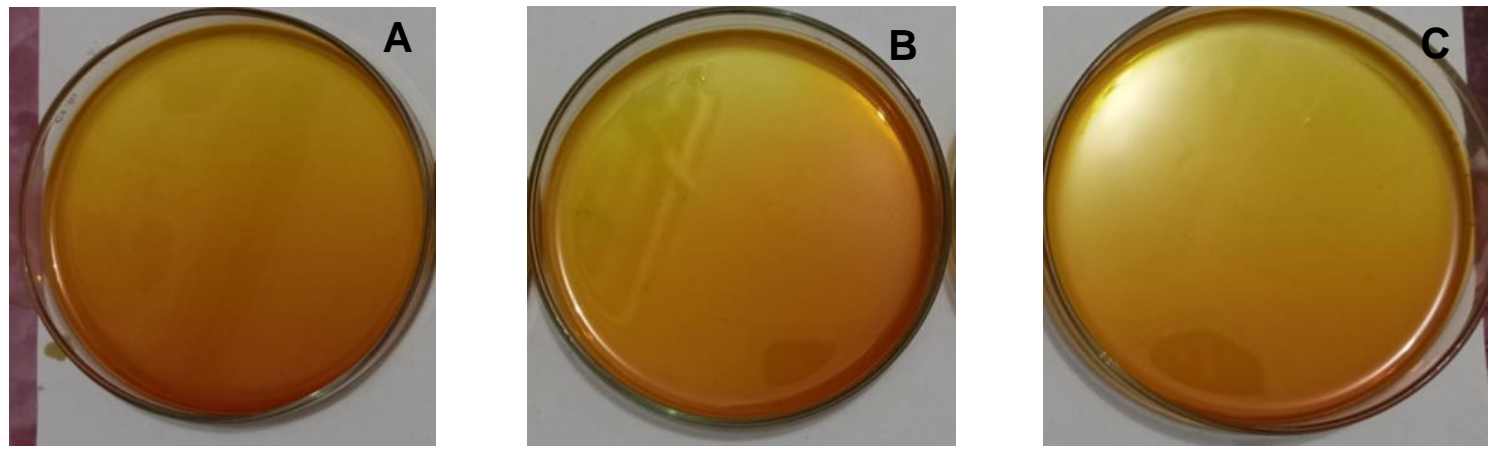

Gambar 5. (a) Minyak Nilam Murni, (b) Minyak Nilam+ Adsorben Mikro MMT

(c) Minyak Nilam+ Adsorben Hasil Interkalasi Mikro MMT dan Mikro kitosan 


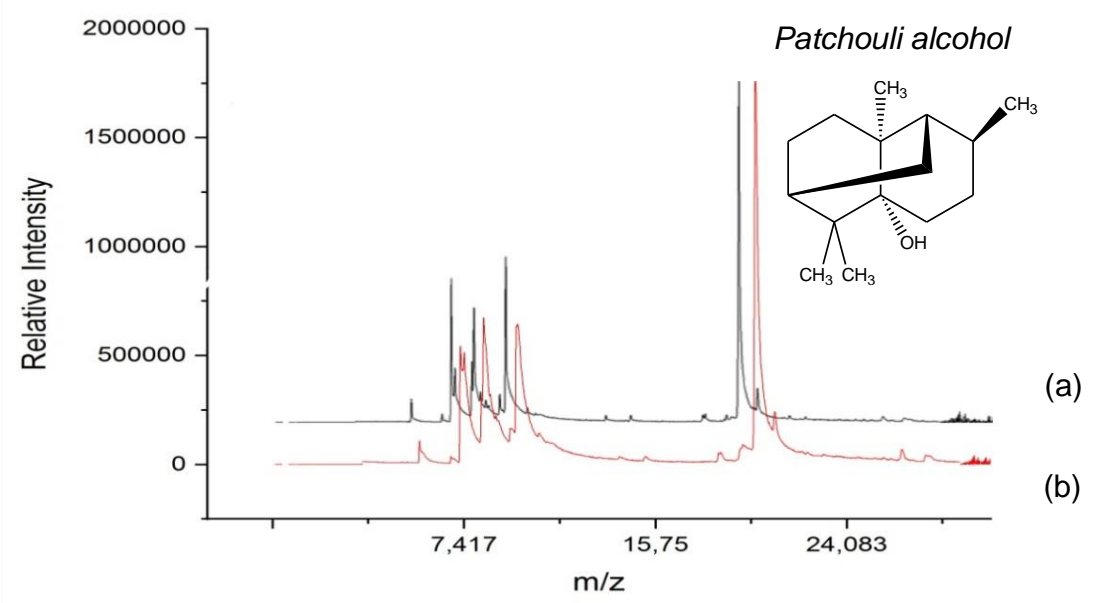

Gambar 6. Kromatogram GC-MS Minyak Nilam (a) Setelah diberi Adsorben Mikro MMT

(b) Setelah diberi Adsorben Hasil Interkalasi Mikro MMT dan Mikro Kitosan

Berdasarkan Gambar 6 diperoleh informasi data GC-MS seperti yang ditunjukkan pada Tabel 5. Persen area yang dihasilkan GCMS pada Tabel 5 didapatkan berdasarkan luas area puncak yang menyatakan banyaknya jumlah suatu senyawa dalam sampel yang diujikan. Semakin besar luas puncak maka semakin tinggi kuantitasnya (Kayaputri et al,. 2014).

Berdasarkan Tabel 5 dapat dilihat bahwa PA pada minyak nilam setelah diadsorpsi adsorben Mikro MMT dengan waktu retensi 20,076 dengan persen area PA sebesar 39,33\% sedangkan PA pada minyak nilam setelah diadsorpsi oleh adsorben hasil interkalasi Mikro MMT dan Mikro Kitosan terdapat pada waktu retensi 20,107 menit dengan persen area PA sebesar 32,35\%. Puncak PA dalam kromatogram minyak nilam terletak pada akhir kromatogram. Hal ini menunjukkan bahwa PA merupakan komponen yang memiliki titik didih relatif tinggi dalam minyak nilam selain senyawa golongan terpenoid (Hardyanti et al., 2016).

Berdasarkan penelitian sebelumnya yang telah dilakukan Machiril et al (2017) menunjukkan bahwa hasil penyerapan methylen blue oleh adsorben MMT-kitosan cenderung menurun. Hasil adsorpsi minyak nilam oleh adsorben interkalasi nano-MMT dengan kitosan cenderung menurun jika dibdaningkan dengan adsorben sebelum diinterkalasi. Persen area PA minyak nilam murni yang diketahui sebesar $30,30 \%$ dan adsorben minyak nilam menggunakan adsorben hasil interkalasi mikro MMT dan mikro kitosan (setelah interkalasi) menghasilkan persen area PA sebesar $32,35 \%$, hal ini mendanakan adanya peningkatan persen area PA sebesar 2,05\%. Namun jika dibdaningkan dengan adsorben Mikro MMT (sebelum interkalasi), persen area PA minyak nilam mengalami penurunan sebesar $6,98 \%$ dari $39,33 \%$ menjadi $32,35 \%$.

MMT mempunyai kapasitas penukaran kation yang tinggi sehingga ruang antar lapis MMT mampu mengakomodasi kation dalam jumlah yang besar (Zaimahwati et al., 2018) sehingga MMT mampu mengakomodasi kation pengotor minyak nilam dengan baik dan menghasilkan persentase PA yang lebih besar dibdaningkan dengan setelah diinterkalasi. Kitosan mempunyai gugus fungsi amina $\left(\mathrm{NH}_{2}\right)$ yang memiliki sepasang elektron bebas pada atom N. Gugus amina ini bertindak sebagai basa Lewis dengan mendonorkan pasangan elektron bebasnya dan dapat menjadi $\mathrm{NH}_{3}{ }^{+}$yang mampu bertukar dengan kation pada interlayer MMT (Pitriani, 2010).

Tabel 5. Informasi Data PA GC-MS

\begin{tabular}{lcc}
\hline \multicolumn{1}{c}{ Adsorben } & $\begin{array}{c}\text { Waktu Retensi } \\
\text { (menit) }\end{array}$ & Area (\%) \\
\hline Minyak Nilam Murni & 20,095 & 30,30 \\
Minyak Nilam + Adsorben Mikro MMT & 20,076 & 39,33 \\
(sebelum interkalasi) & 20,107 & 32,35 \\
$\begin{array}{l}\text { Minyak Nilam + Adsorben Hasil Interkalasi Mikro Mmt DAN } \\
\text { Mikro Kitosan (setelah intekalasi) }\end{array}$ & & \\
\hline
\end{tabular}




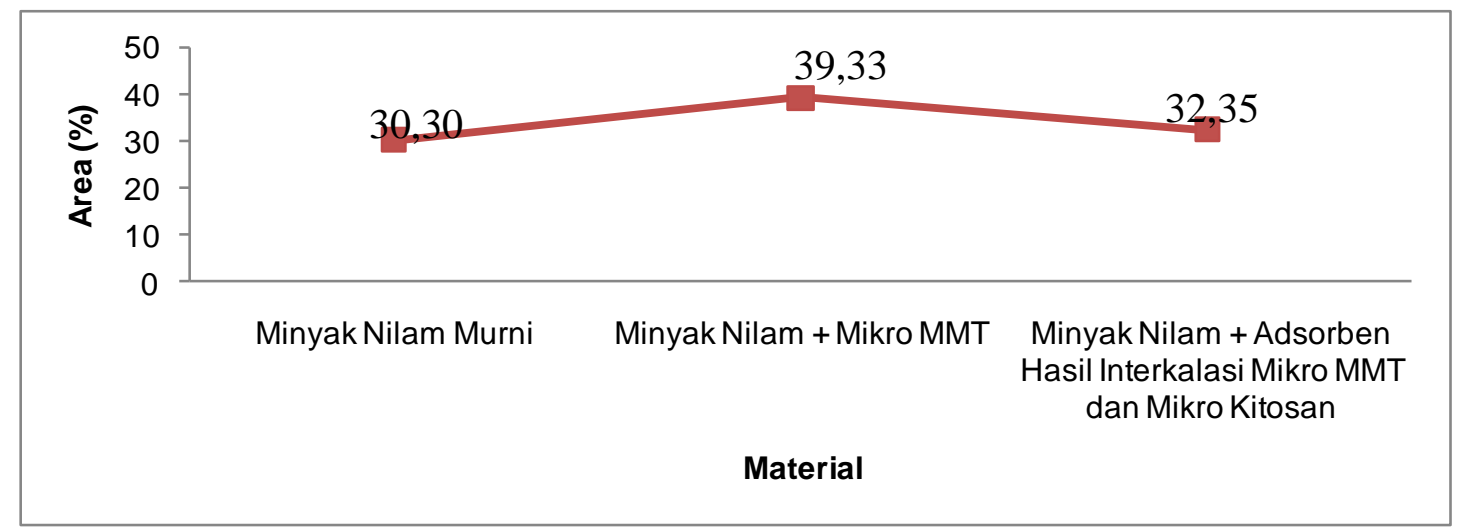

Gambar 6. Grafik Area (\%) PA Minyak Nilam

Adanya penurunan persen area PA setelah dilakukan interkalasi Mikro MMT dengan mikro kitosan disebabkan karena terjadi interaksi tarik menarik elektrostatik antara kelompok ionik dari monomer yang terdapat pada MMT dan kitosan sehingga membentuk molekuler yang lebih besar melalui proses agregasi sehingga logam pengotor tidak dapat masuk ke dalam struktur pori permukaan adsorben. Perbedaan penyerapan minyak nilam antara adsorben Mikro MMT dengan Mikro kitosan, dimana adsorben Mikro MMT (tanpa interkalasi) dapat menyerap minyak nilam lebih besar dibdaningkan dengan

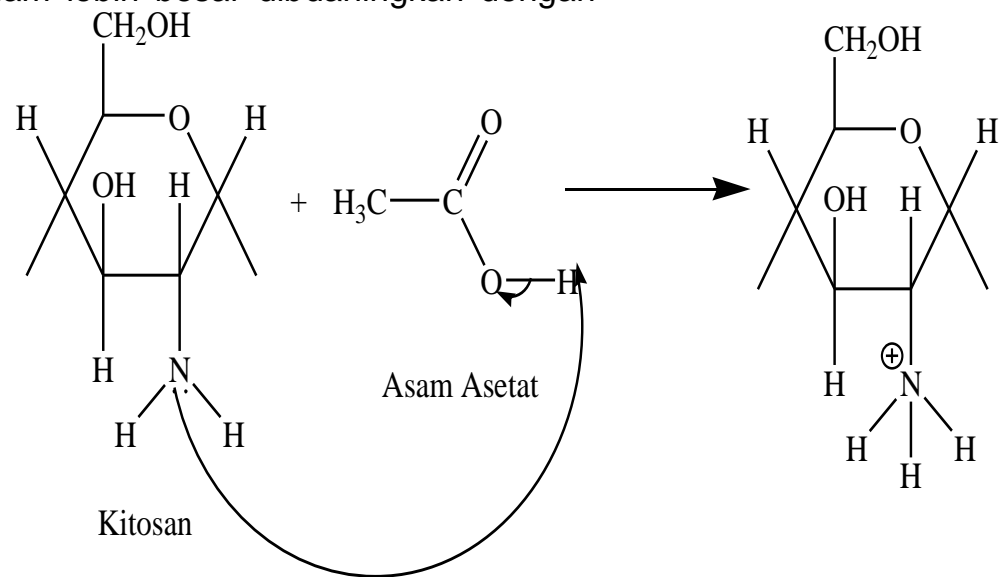

hasil interkalasi Mikro MMT dan Mikro Kitosan (setelah interkalasi) yang disebabkan oleh protonasi gugus amino kitosan pada kondisi asam sesuai dengan reaksi pada Gambar 7 dimana penggunaan asam pada reaksi tersebut mengakibatkan adsorben menjadi bermuatan positif sehingga menyebabkan tolakan antara adsorben interkalasi dengan minyak nilam (Machiril et al., 2017).

Gambar 7. Mekanisme Reaksi Protonasi Kitosan Pada Suasana Asam (Penambahan asam asetat)

\section{KESIMPULAN}

MMT yang digunakan sebagai adsorben untuk meningkatkan mutu minyak nilam diperoleh dari bentonit asal Kabupaten Aceh Tamiang. Hasil pengukuran PSA menunjukkan bahwa MMT memiliki ukuran partikel nano sebanyak $6 \%$ dan selebihnya merupakan partikel mikropori. Semakin halus suatu partikel semakin besar pula luas permukaan yang dapat meningkatkan reaktifitas material.

Nilai jarak antarlapis (basal spacing) relatif tidak mengalami perubahan, interkalasi Mikro MMT dengan Mikro kitosan memiliki basal spacing yang sedikit lebih besar dari Mikro MMT yang belum diinterkalasi. Sebelum diinterkalasi nilai puncak Mikro MMT $2 \theta=11,1210 ; 12,0411$; dan 12,9585 dengan nilai basal spacing 7,9497; 7,3442; dan 6,8263 Å. Setelah diinterkalasi dengan kitosan nilai puncak $2 \theta=10,5815$; 11,3970; dan 12,8707 dengan nilai basal spacing 8,$3537 ; 7,7578$; dan $6,8726 \AA$.

Persen area PA minyak nilam murni sebesar $30,30 \%$ sedangkan persen area PA minyak nilam setelah diinterkalasi Mikro MMT dengan Mikro kitosan sebesar 32,35\%, hal ini mendanakan adanya peningkatan persen area PA sebesar 2,05\%. Namun jika dibdaningkan dengan adsorben Mikro MMT tanpa kitosan, persen area PA minyak nilam mengalami penurunan sebesar $6,98 \%$ dari $39,33 \%$ menjadi $32,35 \%$. 
Hardyanti, I. S., Septyaningsih, D., Nuraini, I., dan Wibowo A. P. 2016. "Analisis Kadar Patchouli Alcohol Menggunakan Gas Chromatography Pada Pemurnian Minyak Nilam Menggunakan Adsorben Zeolit." In Prosiding Seminar Nasional XI "Rekayasa Teknologi Industri Dan Informasi 2016, 392-395.

Harmawan, T., Yulida, A., dan Fadly. T. A. 2019. "Isolation dan Characterization Montmorillonite Nanoparticles of Aceh Tamiang Bentonite as Patchouli Oil ( Pogostemon cablin) Bleaching." Oriental Journal Of Chemistry 35 (5): 1535-38. https://doi.org/http://dx.doi.org/10.13005/ojc /350509.

Harmawan, T., Ani, W., Danani, P., dan Fadly. T. A. 2021. "Production of Biodiesel Through Transesterification of Crude Palm Oil ( CPO ) Using Montmorillonite Nanoparticles (Nano-MMT) as Heterogeneous Solid Catalyst." Atlantis Press : 69-72.

Harti, R., Allwar dan Fitri N. 2014. "Karakterisasi dan Modifikasi Karbon Aktif Tempurung Kelapa Sawit Dengan Asam Nitrat Untuk Menjerap Logam Besi Dan Tembaga Dalam Minyak Nilam." Indonesian Journal of Chemical Research - Inco.J.Chem.Res. 2 (1): 74-83.

Haryudin, W., dan Maslahah, N. 2011. "Karakteristik Morfologi, Anatomi Dan Produksi Terna Aksesi Nilam Asal Aceh Dan Sumatera Utara." Bul. Littro. 22 (2): 115-126.

Ismuyanto, B., Mardiana, D., dan Hidayati, A. S. D. S. N. 2015. "Malang Melalui Teknologi Ramah Lingkungan Distilasi-Rektifikasi Tekanan Rendah." In Seminar Teknologi Dan Rekayasa (SENTRA), 7-12.

Kayaputri, I. L., Sumanti, D. M., Djali, M., Indiarto, R., dan Dewi, D. L 2014. "Kajian Fitokimia Ekstrak Kulit Biji Kakao ( Theobroma cacao L.)." Chimica et Natura Acta 2 (1): 83-90.

Kurniasari, A. M., Adisyahputra dan Rosman, R. 2010. "Pengaruh Kekeringan Pada Tanah Bergaram NaCl.” Bul. Littro 21 (1): 18-27.

Machiril, D., Jumaeri dan Kusumastuti, E. 2017. "Interkalasi Montmorilonit Dengan Kitosan Serta Aplikasinya Sebagai Adsorben Methylene Blue." Indonesian Journal of Chemical Science 6 (2): 117-24. http://journal.unnes.ac.id/sju/index.php/ijcs.

Muchtar, H., Anova., I. T., dan Yeni, G. 2015. "Pengaruh Kecepatan Pengadukan Dan Kehalusan Gambir Serta Variasi Komposisi Terhadap Beberapa Sifat Fisika Dalam Pembuatan Tinta Cetak." Jurnal Litbang Industri 5 (2): 131-39.

Pitriani, P. 2010. "Sintesis Dan Aplikasi Kitosan
Dari Cangkang Rajungan" Skripsi . Jakarta: Universiitas Islam Negeri Syarif Hidayatullah., 1-99.

Putri, A. I., Sundaryono, A., dan Cdanra, I. N. 2018. "Karakterisasi Nanopartikel Kitosan Ekstrak Daun Ubijalar ( Ipomoea batatas L.) Menggunakan Metode Gelasi Ionik." Jurnal Pendidikan Dan IImu Kimia 2 (2): 203-207.

Riskina, S., Satriandana dan Jalal, R. 2018. "Peningkatan Basal Spacing Bentonit Aceh Utara Menggunakan Surfaktan Anionik Dan Kationik Untuk Aplikasi Cat Pelapis." In Proceeding Seminar Nasional Politeknik Negeri Lhokseumawe, 2:160-164.

Saputra, A. H., Haryono, A., Lasmono, J. A., dan Anshari, M. H. 2011. "Preparasi Koloid Nanosilver Dengan Berbagai Jenis Reduktor Sebagai Bahan Anti Bakteri." Jurnal Sains Materi Indonesia 12 (3): 202208.

Sari, R. P., Erdawati dan Santoso, I. 2013. "Adsorpsi Zat Warna Congo Red Menggunakan Kitosan-Mmt Dengan Metode Fixed-Bed Column." JRSKT 3 (2): 326-333.

Septiana, A. A., Arienata, H. F., dan Kumoro A. C. 2013. "Potensi Jus Jeruk Nipis (Citrus aurantifoli) Sebagai Bahan Pengkelat Dalam Proses Pemurnian Minyak Nilam ( Patchouli Oil) Dengan Metode Kompleksometri." Jurnal Teknologi Kimia Dan Industri 1 (1): 21-28.

Suarya, P. dan Simpen, I. N. 2009. "Interkalasi Benzalkonium Klorida Ke Dalam Montmorillonit Teraktivasi Asam Dan Pemanfaatannya Untuk Meningkatkan Kualitas Minyak Daun Cengkeh." Jurnal Kimia 3 (1): 41-46.

Sumarlan, I. Fatimah, I., dan Wijaya, K. 2013. "Synthesis , Characterization dan Aplication of $\mathrm{TiO} 2$ Alumina Pillared Montmorillonite Photocatalyst." EKSAKTA $13(1-2)$ : 22-32.

Wahyuningsih, P., Tisna, H., \& Halimatussakdiah. 2020. "Synthesis dan Characterization of Acid-Activated Bentonite from Aceh Tamiang." In IOP Conference Series: Materials Science dan Engineering, 1-6. https://doi.org/10.1088/1757899X/725/1/01 2050.

Yudhasasmita, S dan Nugroho, A. P. 2017. "Sintesis Dan Aplikasi Nanopartikel Kitosan Sebagai Adsorben Cd Dan Antibakteri Koliform." Biogenesis 5 (1): 42-48. https://doi.org/http://dx.doi.org/10.24252/bi o.v4i2.3432.

Zaimah, S. 2014. "Pengujian Kualitas Dan Komposisi Kimia Minyak Nilam 
(Pogostemon cablin benth) Setelah Penyimpanan." Indonesian Journal of Chemical Research 2 (1): 1-9.

Wahyudi, S. 2010. Sintesis Nanopartikel Zeolit Secara Top Down Menggunakan Planetary Ball Mill dan Ultrasonikator. Jurnal IImiah Jakarta: Pusat Penelitian dan Pengembangan Teknologi Mineral Dan Batubara, 2 (1): 145-157.
Zaimahwati, Yuniati, Jalal, R., Zhafiri, S., dan Yetri, Y. 2018. "Isolasi Dan Karakterisasi Bentonit Alam Menjadi Nanopartikel Monmorillonit." Jurnal Katalisator 3 (1): 12 18. 